\title{
LITERATUR REVIEW : PENGARUH PEMBERIAN JUS BELIMBING TERHADAP PENURUNAN TEKANAN DARAH PADA PASIEN HIPERTENSI
}

\author{
Eli sujana ${ }^{1}$, Meria Woro Listyorini ${ }^{2 *}$, Ponirah $^{3}$, Ricky Riyanto Iksan ${ }^{4}$ \\ ${ }^{1-3}$ STIKes Bani Saleh, Bekasi, Indonesia, \\ ${ }^{4}$ Akademi Keperawatan Pelni Jakarta \\ Email Korespondensi : meriaworo75@gmail.com
}

Disubmit: 25 Januari 2022 Diterima: 27 Januari 2022 Diterbitkan: 02 Februari 2022 DOI: https://doi.org/10.33024/mnj.v5i2.5937

\section{ABSTRACT: LITERATURE REVIEW: EFFECT OF STARTING JUICE ON REDUCING BLOOD PRESSURE IN HYPERTENSION PATIENTS}

Background: Hypertension is a condition in which a person experiences an increase in blood pressure above normal which results in an increase in morbidity and mortality.

Purpose: The purpose of this study was to determine the effect of star fruit juice on reducing blood pressure in hypertensive patients.

Methods: The research design used in this study is literature review research. Quantitative research with a literature review approach analyzing research journals related to the topic of analysis and search methods using intervention journals to overcome hypertension problems that can be accessed in full text. Search articles using Google Scholar and Sematic Scholar with the first keywords Hypertension Patients and Giving star fruit juice and Lowering blood pressure and Quasi Experiments, getting 256 results. Articles published in 2012-2021 in Indonesian. The initial screening analysis got 14 which were then read in full.

Results: research from 10 articles all stated that there was an effect of giving star fruit juice on reducing blood pressure in hypertensive patients.

Conclusion: This proves that the effect of star fruit juice on reducing blood pressure in patients with hypertension.

Keywords: Hypertension, Starfruit Juice, Literature Review, Effect, Blood Pressure

INTISARI: LITERATUR REVIEW: PENGARUH PEMBERIAN JUS BELIMBING TERHADAP PENURUNAN TEKANAN DARAH PADA PASIEN HIPERTENSI

Latar Belakang: Hipertensi merupakan keadaan di mana seorang mengalami peningkatan tekanan darah diatas normal yang mengakibatkan peningkatan angka kesakitan dan kematian batasan tekanan darah yang masih dianggap normal 140/90 $\mathrm{mmHg}$, sedangkan tekanan darah 160/95 mmHg dinyatakan hipertensi

Tujuan : Tujuan literatur review ini adalah untuk mengetahui pengaruh jus belimbing terhadap penurunan tekanan darah pada penderita hipertensi. Desain penelitian yang digunakan dalam penelitian ini adalah penelitian literatur review. 
Metode : penelitian kuantitatif dengan pendekatan literatur riview menganalisis jurnal penelitian yang berkaitan dengan topik analisis dan metode pencarian menggunakan jurnal intervensi untuk mengatasi masalah hipertensi yang dapat diakses full text. Pencarian artikel menggunakan Google Scholar dan Sematic Scholar dengan kata kunci yang pertama Pasien Hipertensi dan Pemberian jus belimbing dan Menurunkan tekanan darah dan Quasi Experimen di dapatkan 256 hasil. Artikel terbitan tahun 2012-2021 dalam bahasa Indonesia. Analisa Screening awal mendapatkan 14 yang kemudian di baca secara utuh.

Hasil : penelitian dari 10 artikel semua menyatakan bahwa ada pengaruh pemberian jus belimbing terhadap penurunan tekanan darah pada pasien hipertensi.

Kesimpulan : Hal ini membuktikan bahwa pengaruh jus belimbing terhadap penurunan tekanan darah pada penderita hipertensi.

Kata Kunci: Hipertensi, Jus Belimbing, Literature Review, Pengaruh, Tekanan Darah

\section{PENDAHULUAN}

Hipertensi merupakan suatu keadaan di mana seorang mengalami peningkatan tekanan darah diatas normal yang mengakibatkan peningkatan angka kesakitan (morbiditas) dan kematian (mortalitas). Tekanan darah 140/90 $\mathrm{mmHg}$ di dasarkan pada dua fase dalam setiap denyut jantung yaitu fase sistolik 140 menuju fase darah yang sedang dipompa oleh jantung dan fase diastolic 90 menunjukkan fase darah yang kembali kejantung. Menurut WHO, batasan tekanan darah yang masih dianggap normal 140/90 mmHg, sedangkan tekanan darah 160/95 $\mathrm{mmHg}$ dinyatakan hipertensi. Hipertensi sering di abaikan karena tidak menunjukkan gejala yang dapat dilihat dari luar sehingga di sebut the silent killer. Hipertensi menjadi masalah serius di dunia yang sering ditemukan di masyarakat, karena prevalensi nya terus meingkat dari tahun k tahun. (Vino Rika Novia et al., 2018 ; Ibrahim et al., 2021).

$$
\text { Data World Health }
$$

Organization (WHO) tahun, 2018 dalam Andika Herlina MP, Siti Aisyah Nur, 2020) ditemukan sekitar 50 juta ( $23,8 \%$ orang dewasa Amerika menderita hipertensi.penderita hipertensi juga menyerang penduduk Thailand sekitar $19 \%$, Vietnam 35,6\%, Singapura 26,9 \%, Malaysia 31,9\%. Indonesia memiliki angka yang cukup tinggi yaitu $15 \%$ dari 230 juta penduduk , 35 juta penduduk Indonesia menderita hipertensi. Prevalensi terjadi nya hipertensi di Indonesia dari hasil Riset Kesehatan Dasar (RisKesDas) 2018 menunjukkan bahwa prevalensi hipertensi sebanyak 34,1\%. Tertinggi di Kalimantan Selatan 44,3\%, di Jawa Barat menempati urutan kedua 39,6\%. Prevalensi hipertensi di kota Bekasi sebesar $13,8 \%$.

Hipertensi bila tidak diobati dengan benar akan mengakibatkan komplikasi yang meliputi krisis hipertensi, penyakit arteri perifer, aneurisma aorta dissecting, PJK, angina pectoris, infark miokard, gagal jantung, gagal ginjal, aritmia, serangan iskemik sepintas ( transient ischemic attack, TIA ), stroke, retinopati, ensefalopati hipertensi dan kematian medadak kondisi ini haruslah mendapatkan penanganan yang cepat (Dasuki et al., 2018). Penanganan darah tinggi dapat dilakukan dengan cara farmakologis 
(dengan obat ) atau terapi non farmakologis ( tanpa obat ).

Penanganan darah tinggi dengan cara farmakologis dengan memberikan obat hipertensi, Terdapat lima kelompok utama obat antihipertensi yaitu diuretik tiazid, beta-blocker, ace inhibitor, alfablocker,dan calcium chanel blocker. Obat ini mempunyai efek vasodilatasi langsung pada arteriol yang menyebabkan efek hipotensi berkelanjutan. (Nurrahmani, 2014 dalam Dasuki et al., 2018). Penanganan non farmakologis yaitu membiasakan pola hidup sehat seperti tidak merokok, tidak minum minuman keras, rajin berolahraga dan menejemen diet. Diet yang diberikan pada penderita hipertensi dapat berupa tomat, semangka, pisang, avokad, buah belimbing, mentimun dan buah naga (Suprato, 2013 dalam Andika Herlina MP,Siti Aisyah Nur, 2020). Buah belimbing salah satu pengobatan non farmakologis yang sangat bermanfaat dalam membantu menurunkan tekanan darah karena kandungan serat, pro vitamin $A$, vitamin $C$, vitamin $B 1$, vitamin $B 2$, fosfor, kalsium, zat besi, kalium yang bermanfaat menurunkan tekanan darah (Ruslianti, 2013 dalam Andika Herlina MP, Siti Aisyah Nur, 2020). Buah belimbing memiliki sifat analgetik, antihipertensi dan diuretik (Bayu dan Novairi, 2013). Diuretik memiliki efek antihipertensi dengan meningkatkan pelepasan air dan garam natrium yang akan mengikat lemak dan berdampak pada tidak bertambah nya berat badan, salah satu faktor risiko hipertensi.

Penelitian DASH (Dietary Approaches to Stop Hypertension) telah dikatakan bahwa untuk menurunkan tekanan darah sangat dianjurkan mengkonsumsi makanan yang tinggi kalium dan serat. Buah belimbing mengandung kalium dan natrium dengan perbandingan sehingga sangat bagus untuk penderita hipertensi (Nathalia V, 2017 dalam Fierdiana, 2017). Hasil penelitian (Legi Nonce N, 2020) menjabarkan mengenai sebelum di beri perlakuan terapi jus belimbing sebagian besar dari responden mengalami hipertensi ringan sebanyak 28 orang (54.9\%) dan di ketahui sesudah di berikan perlakuan terapi jus belimbing sebagian besar dari responden mengalami tekanan darah normal yaitu sebanyak 26 orang $(51,0 \%)$ penelitian ini menunjukkan ada pengaruh jus belmbing terhadap penurunan tekanan darah. Peranan kalium bersama klorida menbantu menjaga tekanan osmotic dan keseimbangan asam basa. Kalium menjaga tekanan osmotik dalam cairan intraseluler dan sebagian terikat dengan protein, kalium juga menbantu mengaktivasi reaksi enzim seperti piruvat kinase yang menghasilkan asam piruvat dalam proses metabolisme karbohidrat.

Dari data dan uraian di atas bahwa pemberian jus belimbing terbukti efektif untuk menurunkan tekanan darah.tetapi fakta di lapangan masih ditemukan banyak pasien dengan hipertensi yang hanya menggunakan pengobatan farmakologis berupa obat hipertensi dan tidak menggunakan pengobatan non farmakologis sebagai pengobatan alternatif lain.Hal ini terjadi karena banyak masyarakat yang belum mengetahui dan meyakini manfaat buah belimbing.Sebagai seorang perawat selain berkolaborasi memberikan pengobatan farmaklologis perawat bisa juga memberikan intervensi berupa penyuluhan akan manfaat dari jus 
belimbing untuk membantu menurunkan tekanan darah.Pengobatan secara herbal dengan mengkonsumsi jus belimbing selain mudah dilakukan juga dampak negatif dari terapi sangat minim.

\section{METODE}

Formulasi PICO

Dalam metode penulisan Karya Tulis Ilmiah ini peneliti Desain Penelitian yang digunakan yaitu literature review. Literature review merupakan uraian teori,temuan dan artikel penelitian lainnya untuk di jadikan landasan kegiatan penelitian. Tujuan melakukan literature review adalah memberi informasi, menunjukan pro kontra atau mengarah bahwa penelitian ini penting. Literature review berisi
Berdasarkan uraian di atas penulis tertarik untuk menganalisa literatur (jurnal) yang berisi tentang pengaruh pemberian jus belimbing terhadap penurunan tekanan darah pada pasien hipertensi lansia

artikel yang membantu memberikan bentuk dari argument atau narasi yang dibangun peneliti. Penelusuran artikel ini menggunakan google scholar, semantic scholar, dengan periode publikasi tahun 2012-2021. Adapun strategi pencarian artikel yang dilakukan yaitu dengan Formulasi PICO. Untuk meyakinkan tenaga kesehataan pengaruh jus belimbing untuk pasien hipertensi perlu dilakukan pencarian literatur.

\section{HASIL}

\begin{tabular}{|c|c|c|c|}
\hline No. & Judul Artikel & Penulis & Keterangan \\
\hline 1. & $\begin{array}{l}\text { Pengaruh jus belimbing } \\
\text { manis ( Averrhoa } \\
\text { Carambola Linn ) } \\
\text { terhadap tekanan darah } \\
\text { pada lansia dengan } \\
\text { hipertensi Di Desa Lemah } \\
\text { Putih Kec.Brati Kab. } \\
\text { Grobogan ) }\end{array}$ & $\begin{array}{l}\text { Noor Cholifah, Suyatno, } \\
\text { Dewi Hartinah ( } 2018 \text { ) }\end{array}$ & $\begin{array}{l}\text { Sesuai kata } \\
\text { kunci } \\
\text { pencarian }\end{array}$ \\
\hline 2. & $\begin{array}{l}\text { Pengaruh pemberian jus } \\
\text { belimbing terhadap } \\
\text { penurunan tekanan darah } \\
\text { pada lansia penderita } \\
\text { hipertensi di kelurahan } \\
\text { Timbangan Padang } \\
\text { Sidimpuan }\end{array}$ & $\begin{array}{l}\text { Nanda Masraini } \\
\text { Daulay, Lisda Yanti } \\
\text { Siregar,Tiodora Situmeang } \\
\text { ( 2016 ) }\end{array}$ & $\begin{array}{l}\text { Sesuai kata } \\
\text { kunci } \\
\text { pencarian }\end{array}$ \\
\hline 3. & $\begin{array}{l}\text { Pengaruh pemberian jus } \\
\text { belimbing terhadap } \\
\text { penurunan tekanan darah } \\
\text { pada pasien hipertensi di }\end{array}$ & $\begin{array}{l}\text { Sri Inti, Nikmatul Firdaus } \\
\text { ( } 2020 \text { ) }\end{array}$ & $\begin{array}{l}\text { Sesuai kata } \\
\text { kunci } \\
\text { pencarian }\end{array}$ \\
\hline
\end{tabular}




\begin{tabular}{|c|c|c|c|}
\hline & $\begin{array}{l}\text { Puskesmas Ngadiluwih } \\
\text { Kabupaten Kediri }\end{array}$ & & \\
\hline 4. & $\begin{array}{l}\text { Pengaruh pemberian jus } \\
\text { averrhoa carambola } \\
\text { terhadap penurunan } \\
\text { tekanan darah pada } \\
\text { lansia penderita } \\
\text { hipertensi }\end{array}$ & $\begin{array}{l}\text { Putri Aulia Arza,Andri } \\
\text { Irawan } \\
\text { ( } 2018 \text { ) }\end{array}$ & $\begin{array}{l}\text { Sesuai kata } \\
\text { kunci } \\
\text { pencarian }\end{array}$ \\
\hline 5. & $\begin{array}{l}\text { Pengaruh jus belimbing } \\
\text { terhadap penurunan } \\
\text { takanan darah pada lansia } \\
\text { di kelurahan tanjung paku } \\
\text { wilayah kerja puskesmas } \\
\text { tanjung paku kota solok }\end{array}$ & $\begin{array}{l}\text { Armanda Tri Murti Ningsih } \\
\text { ( } 2019 \text { ) }\end{array}$ & $\begin{array}{l}\text { Sesuai kata } \\
\text { kunci } \\
\text { pencarian }\end{array}$ \\
\hline 6. & $\begin{array}{l}\text { Pengaruh pemberian jus } \\
\text { belimbing ( Averrhoe } \\
\text { Carambola Linn ) } \\
\text { terhadap penurunan } \\
\text { tekanan darah pada } \\
\text { penderita hipertensi di } \\
\text { wilayah kerja Puskesmas } \\
\text { Andalas }\end{array}$ & $\begin{array}{l}\text { Vino Rika } \\
\text { Novia,Sujarwo,Mustika } \\
\text { Ulfa Wulandari } \\
\text { ( } 2018 \text { ) }\end{array}$ & $\begin{array}{l}\text { Sesuai kata } \\
\text { kunci } \\
\text { pencarian }\end{array}$ \\
\hline 7. & $\begin{array}{l}\text { Pengaruh jus belimbing } \\
\text { terhadap penurunan } \\
\text { tekanan darah pada } \\
\text { penderita hipertensi ( } \\
\text { studi di RT 05 Desa } \\
\text { Pangkut Kecamatan Arut } \\
\text { Utara Kabupaten } \\
\text { Kotawaringin Barat } \\
\text { Provinsi Kalimantan } \\
\text { Tengah }\end{array}$ & $\begin{array}{l}\text { Cipta Nur Jihaddin,Luluk } \\
\text { Sulistiyono,Jon Persen } \\
\text { Manik } \\
\text { ( 2019) }\end{array}$ & $\begin{array}{l}\text { Sesuai kata } \\
\text { kunci } \\
\text { pencarian }\end{array}$ \\
\hline 8. & $\begin{array}{l}\text { Pengaruh pemberian jus } \\
\text { belimbing terhadap } \\
\text { tekanan darah pada } \\
\text { penderita hipertensi di } \\
\text { wilayah kerja Puskesmas } \\
\text { Lubuk Buaya Padang }\end{array}$ & $\begin{array}{l}\text { Andika Herlina MP,Siti } \\
\text { Aisyah Nur,Fitri Wulandari } \\
\text { ( } 2021 \text { ) }\end{array}$ & $\begin{array}{l}\text { Sesuai kata } \\
\text { kunci } \\
\text { pencarian }\end{array}$ \\
\hline 9. & $\begin{array}{l}\text { Pengaruh pemberian jus } \\
\text { buah belimbing wuluh } \\
\text { ( Averrhoa Blimbi } L \text { ) } \\
\text { terhadap penurunan }\end{array}$ & $\begin{array}{l}\text { Dasuki, Maulani, } \\
\text { Muhammad Zulni } \\
\text { ( 2018) }\end{array}$ & $\begin{array}{l}\text { Sesuai kata } \\
\text { kunci } \\
\text { pencarian }\end{array}$ \\
\hline
\end{tabular}


tekanan darah pada

penderita hipertensi di

Puskesmas Rawasari Kota

Jambi

10. Pengaruh pemberian jus

belimbing manis terhadap

penurunann tekanan

Riswahyuni Widhawati,

Sesuai Kata

darah pada penderita

Eka Indri Widiyastuti,

Kunci

hipertensi di panti

Oryza Intan Suri

Werdha Bina Bhakti

Serpong Tahun 2018 (2018)

\section{PEMBAHASAN}

Populasi dari sepuluh jurnal yang populasinya lansia ada lima, Salah satunya penelitian dari Riswahyuni Widhawati dkk dengan jumlah sampel 30 responden dengan karakteristik responden Usia 60-90 Tahun, jenis kelamin, IMT,mengkonsumsi makanan berlemak, mengkonsumsi garam berlebih, stress dan lainnya. Penelitian yang tidak secara detail menjelaskan karakteristik respondennya salah satu contoh penelitian dari Armada Tri Murtiningsih menjelasakan populasinya berjumlah 27 orang, sampel di ambil menggunakan purposive sampling diperoleh sebanyak 5 orang. Penelitian yang jumlah respondenya di bagi 2 kelompok penelitian dari Noor Cholifah dkk dan penelitian dari Nanda Masraini Daulay dkk, Salah satu contoh penelitian dari Nanda Masraini Daulay dengan jumlah populasi 28 orang terbagi 2 kelompok eksperimen 14 responden dan kelompok kontrol 14 responden dengan karakteristik jenis kelamin perempuan lebih banyak jumlahnya 25 responden, Umur 45- 48 dengan jumlah 10 responden , pekerjaan petani dengan jumlah 14 responden dan pendidikan SMA dengan jumlah 15 responden. Dari sekaian jurnal rata-rata populasinya usia 45 -55 dan jenis kelamin perempuan yang banyak menderita hipertensi.

Intervensi pemberian jus belimbing yang tidak di jelaskan secara detail, salah satu contoh penelitian penelitian yang dilakukan Riswahyuni Widhawati dkk tidak menjelaskan dengan detail intervensi yang dilakukannya. Pada penelitian Putri Aulia Azra dkk menjelaskan intervensinya secara detail dengan memberikan jus belimbing manis, sebanyak $200 \mathrm{ml}$ dengan komposisi (150 gr belimbing manis, $50 \mathrm{ml}$ air dan $10 \mathrm{gr}$ madu) intervensi dilakukan selama 7 hari kepada lansia penderita hipertensi dengan frekuensi 1 kali sehari.

Penelitian yang di lakukan Nanda Masrani Daulay dkk dan Noor Cholifah dkk dengan control group atau kelompok pembanding, dengan pemberian jus belimbing yang terdiri dari 2 kelompok intervensi dan kelompok kontrol, kelompok kontrol tidak di berikan jus belimbing hanya dilakukan pengukuran tekanan darah, sedangkan kelompok intervensi di berikan jus belimbing. 
Perbedaan yang signifikan dari sepuluh artikel di dalam pembahasan menyatakan bahwa ada perbedaan sebelum pemberian jus belimbing dan sesudah pemberian jus belimbing terhadap penurunan tekanan darah pada penderita hipertensi. Salah satu artikel yang banyak penurunan tekanan darah yang di tulis Putri Aulia Azra,Andri Irawan dengan usia 45-65 tahun rata-rata penuruanan tekanan darah sistole $40 \mathrm{mmHg}$ dan diastolenya $13 \mathrm{mmHg}$. Penelitian yang dilakukan Riswahyuni Widhawati dengan karakteristik usia 60-90 tahun dengan pemberian jus belimbing rata-rata penurunan tekanan darah sistole 9 $\mathrm{mmHg}$ dan diastole $6 \mathrm{mmHg}$. Untuk usia di atas 60 tahun dengan diberikan jus belmbing penurunanya sedikit di bandingkan usia di bawah 60 tahun.

Penjelasan mengenai pelaksanan intervensi terutama dari waktu pelaksanaan hanya 5 jurnal yang menjelasakan waktu intervensinya terutama dari salah satu contoh penelitian yang paling lama penelitian dari Dasuki, Maulana, Muhammad Zuhri enelitian ini di lakukan pada tanggal 14 Juli- 28 Juli tahun 2017 (2 minggu) dengan frekuensi pemberian 1 kali sehari dengan rata- rata penurunan tekanan darah sistole $29 \mathrm{mmHg}$ dan diastole $5,88 \mathrm{mmHg}$. Penelitian paling singkat dilakukan oleh Armanda Tri Murti Ningsih dilakukan selama 3 hari dengan frekuensi pemberian 2 kali sehari, rata-rata penurunan tekanan darah 10-20 mmHg.

\section{Pembahasan Hasil Telaah Artikel Berdasarkan Teori dan Hasil Penelitian}

Hipertensi didefinisikan sebagai tekanan darah sistolik lebih dari $140 \mathrm{mmHg}$ dan tekanan diastolik lebih dari 90 mmHg, berdasarkan pada dua kali pengukuran atau lebih. (Brunner \& Suddart, 2013). Penanganan darah tinggi dapat dilakukan dengan cara farmakologis atau non farmakologis. Farmakologis dengan obat antihipertensi yaitu diuretik tiazid, beta-blocker, ace inhibitor, alfa-blocker, dan calcium chanel blocker. Obat ini mempunyai efek vasodilatasi langsung pada arteriol yang menyebabkan efek hipotensi berkelanjutan. (Nurrahmani, 2014 dalam Dasuki et al., 2018). Salah satu pengobatan non farmakologis yaitu membiasakan pola hidup sehat seperti tidak merokok, tidak minum minuman keras, rajin berolahraga dan menejemen diet. Diet yang diberikan pada penderita hipertensi dapat berupa tomat, semangka, pisang, avokad, buah belimbing, mentimun dan buah naga (Suprato, 2013 dalam Andika Herlina MP, Siti Aisyah Nur, 2020). Buah belimbing salah satu pengobatan non farmakologis yang sangat bermanfaat dalam membantu menurunkan tekanan darah karena kandungan serat, pro vitamin $A$, vitamin $C$, vitamin B1, vitamin B2, fosfor, kalsium, zat besi, kalium yang bermanfaat menurunkan tekanan darah (Ruslianti, 2013 dalam Andika Herlina MP, Siti Aisyah Nur, 2020). Buah belimbing memiliki sifat analgetik,antihipertensi dan diuretik (Bayu dan Novairi, 2013).

Khasiat buah belimbing bagi kesehatan mulai dari provitamin $A$, vitamin C, B1 dan B2 sampai beragam mineral penting seperti fosfor, kalsium, zat besi, kalium, serat, dan pectin mampu menurunkan kadar kolesterol dan tekanan darah tinggi (hipertensi) berkat kandungan serat larut dan antioksidan di dalamnya. Serat larut dalam belimbing juga berguna untuk mencegah penyakit 
stroke, obesitas, dan memelihara kesehatan pencernaan.

Klasifikasi yang terdapat dalam sepuluh jurnal yang di teliti rata-rata tekanan darah $140 \mathrm{mmHg}-160 \mathrm{mmHg}$ dengan hipertensi ringan atau stadium 1, dengan di berikan intervensi jus belimbing terdapat pengaruh yang signifikan pada usia 45- 55 tahun, tetapi pada usia di atas 60-90 tahun penggunaan jus belimbing kurang efektif untuk diberikan. Untuk jenis kelamin perempuan lebih banyak yang menderita tekanan darah tinggi dengan usia diatas 45 tahun. Tingkat pendidikan rendah juga sangat mempengarui tekanan darah karena faktor kurang pengetahuan. karena banyak masyarakat yang belum mengetahui dan meyakini manfaat buah belimbing. Sebagai seorang perawat selain berkolaborasi memberikan pengobatan farmaklologis perawat bisa juga memberikan intervensi berupa penyuluhan akan manfaat dari jus belimbing untuk membantu menurunkan tekanan darah.Pengobatan secara herbal dengan mengkonsumsi jus belimbing selain mudah dilakukan juga dampak negatif dari terapi sangat minim

\section{KESIMPULAN \\ Jurnal penelitian berdasarkan \\ kata kunci dan tahun sesuai pendekatan PICOT di dapatkan 256 hasil, Artikel terbitan tahun 2012-2021 dalam bahasa Indonesia. Analisa Screening awal mendapatkan 14 yang kemudian di baca secara utuh, dari hasil membaca secara utuh di lakukan analisis unsur artikel. Hasil penelitian dari 10 artikel semua menyatakan bahwa ada pengaruh pemberian jus belimbing terhadap penurunan tekanan darah pada pasien hipertensi.}

\section{SARAN}

\section{Bagi Perawat}

Perawat bisa memberikan edukasi kepada masyarakat pentingnya pengobatan herbal untuk membantu menurunkan tekanan darah tinggi dan menjadi salah satu intervensi mandiri keperawatan dalam mengatasi tekanan darah tinggi.

\section{Bagi Institusi Pendidikan}

Institusi pendidikan kesehatan sebagai salah satu wadah untuk terus mengembangkan penatalaksanaan secara teknis sebagai fasilitator dalam mengembangkan terapi non farmakologi ini terutama penyuluhan.

\section{DAFTAR PUSTAKA}

Andika Herlina MP, Siti Aisyah Nur, F. W. (2020). Pengaruh pemberian jus belimbing terhadap tekanan darah pada penderita hipertensi. Jurnal Syedza Saintika, 459-474.

Brunner \& Suddarth ,(2013).Buku Ajar Keperawatan Medikal Bedah Edisi 12. Jakarta EGC

Dasuki, Maulani, \& Zulni, M. (2018). Pengaruh Pemberian Jus Buah Belimbing Wuluh ( Averrhoa Bilimbi L ) terhadap penurunan Tekanan Darah Pada Penderita Hipertensi Di Puskesmas Rawasari Kota Jambi. Wacana Kesehatan, 3(1), 260-269.

Ernanda , Rizky ( 2016 ). Satuan Acara Penyuluhan Terapi Jus Hipertensi.

Semaranghttp://jurnal.akperdha rmawacana.ac.id/index.php/wac ana/article/viewFile/64/34

Fierdiana, L. (2017). Pengaruh Pemberian Jus Belimbing Terhadap Penurunan Tekanan Darah Penderita Hipertensi Di Desa Sendangrejo.

Legi Nonce N, G. K. . L. (2020). JUS BELIMBING MANIS ( Averrhoa Carambola ) PENDERITA 
HIPERTENSI. 12(2), 113-125.

Lely Noormindhawati , Farida Wahyu N. ( 2016 ). Jus Sehat Untuk Sembuhkan Berbagai Penyakit : Cet 1 Jakarta

Meliala, Y. M. (2018). Efek pemberian jus belimbing terhadap tekanan darah penderita hipertensi di Kecamatan Berastagia , Kabupaten Karo, Sumatera Utara. Muslikah. (2018). Asuhan Keperawatan Pemberian Jus Belimbing Terhadap Penurunan Tekanan Darah Pada Pasien Hipertensi Di Puskesmas 1 Kecamatan Mranggen Kab. Demak . 8-29

Musyayyadah, S. A., Darni, J., \& Fathimah, F. (2020). Pengaruh Larutan Madu terhadap Tekanan Darah Lanjut Usia Hipertensi. Nutri-Sains: Jurnal Gizi, Pangan Dan Aplikasinya, 3(2), 83. https://doi.org/10.21580/ns.201

9.3.2.3425

Nugraha, G., \& Badrawi, I. (2018). Pedoman Teknik Pemeriksaan Laboratorium Klinik. Trans Info Media.

Novia, V. R., Sujarwo, \& Wulandari, M. U. (2018). Pengaruh Pemberian Jus Belimbing (Averrhoe Carambola Linn) Terhadap Penurunan Tekanan Darah Pada Penderita Hipertensi di Wilayah Kerja Puskesmas Andalas Tahun 2018. Jurnal Kesehatan Saintika Meditory, 1(1), 64-69.

Putri Aulia Azrz, A. I. (2018). Pengaruh Pemberian Jus Averrhoa carambola terhadap Penurunan Tekanan Darah pada Lansia Penderita Hipertensi. Jurnal Kesehatan, $\quad 9(1), \quad 51$. https://doi.org/10.26630/jk.v9i 1.742

RISKESDAS KEMENKES RI. ( 2018 ). Laporan hasil riset kesehatan dasar Indonesia : Departemen Kesehatan

RI.

Tryfauzi. (2016). Faktor-faktor yang Berhubungan dengan Tingkat Hipertensi di Wilayah Kerja Puskesmas Demak. Skripsi, 1-67. 